\title{
Environmental Factors Affecting Sporulation of Fuligo septica (Myxomycetes) on Sugar Cane Bagasse
}

\author{
Alda de Andrade Chiappeta ${ }^{1 *}$, Kêsia Xisto Fonseca R. de Sena ${ }^{1}$ and Laise de Holanda \\ Cavalcanti ${ }^{2}$ \\ ${ }^{I}$ Departamento de Antibióticos; Universidade Federal de Pernambuco; Cidade Universitária; 50670-901; Recife - PE - \\ Brazil. ${ }^{2}$ Departamento de Botânica; Universidade Federal de Pernambuco; Cidade Universitária; 50670-901; Recife - \\ PE - Brazil
}

\begin{abstract}
The influence of environmental factors on sporulation of Fuligo septica (L.) Wigg. and the abundance of this species on sugar cane bagasse (Saccharum officinarum L.), stored outdoors was studied.In Northeastern Brazil, between January/1997 and January/1998, a total of 29 specimens were collected through monthly collections of aethalia. The relationships between the abundance of aethalia and rainfall, temperature, relative humidity of the air and insolation were studied. Results indicated that on the substrate analyzed, F. septica was an abundant species. Sporulation occurred in all seasons of the year, with a well-defined peak at the end of winter and beginning of spring (August/September), which was strongly influenced by rainfall.
\end{abstract}

Key words: Fuligo septica, Myxomycetes, phenology, environmental factors

\section{INTRODUCTION}

How important the occurrence of Fuligo septica (L.) Wigg. on sugar cane bagasse is, may be evaluated through the effects it has on industrie, that use cane bagasse as a raw material or as fuel, and on rural workers employed in these industries. It is well known that this microorganism causes asthma and allergenic rhinitis (Santilli et al., 1985; Gianini et al.,1975; McElhenney and McGovern, 1970) and, it may be responsible for some of the diseases affecting workers handling cane bagasse. Lacey (1974) described losses caused in the utilization of sugar cane bagasse due to the presence of cellulolytic fungi (Myxomycetes and others) and thermophilic actinomycetes. The constant presence of $F$. septica on sugar cane bagasse, due to the probable cellulolytic activity of its plasmodium, may contribute to its faster deterioration, thus reducing its use potential.

The scarcity or richness of Myxomycetes sporocarps in an environment is a result of a combination of factors that have been reported by several authors (Farr, 1976; Maimoni-Rodella and Gottsberger, 1980; Alexopoulos et al., 1996).

In a study on sporulation of Myxomycetes in a woody savanna (Cerrado) at Botucatu (São Paulo State, Brazil), F. septica was reported only for April (Maimoni-Rodella and Gottsberger, 1980). It was found that though rainfall in April was of only $65 \mathrm{~mm}$, rainfall of the preceding two months reached much higher levels $(152 \mathrm{~mm}$ in March and $239 \mathrm{~mm}$ in February). This fact showed that the amount of rainfall of the period preceding the collection had a strong influence on the sporulation of this species.

\footnotetext{
* Author for correspondence
} 
Correlation between abundance of sporocarps and rainfall and between species richness and temperature in a sub-perennial tropical forest in Mexico were significantly positive when compared to climatic data for the preceding two months. Correlation between diversity and rainfall was also positive when data for a same month were compared. F. septica figures among the species identified. However, only a single collection was reported for this species (in October), at end of the rainy season (Ogata et al.,1996). Scarcity of some species, as F. septica, has been explained by the authors by the capacity it has of remaining in a plasmodia state for long periods.

Pôrto and Cavalcanti (1984), analyzing the influence of environmental factors on the occurrence of Myxomycetes in a seasonal perennial coastal forest in Northeastern Brazil, concluded that the most important climatic factor for the diversity and frequency of species in the region was rainfall. Temperature and humidity of the air in such environment have slight variations, remaining at high levels, thus creating favorable conditions for the development of these organisms along the year. In this paper, we described the influence of rainfall, insolation, temperature and relative humidity of the air on sporulation of Fuligo septica and the abundance of this species on sugar cane bagasse (Saccharum officinarum L.), stored outdoors in Northeastern Brazil.

\section{MATERIAL AND METHODS}

The Companhia Indústrias Brasileiras Portela, located at the municipality of Jaboatão dos Guararapes, Humid Forest Zone, Pernambuco State, has a permanent supply of sugar cane bagasse (Saccharum officinarum L.), which is stored outdoors and propitiates the development of a diversified microbiota. Between January/1997 and January/1998, samples of $F$. septica sporulated on this were collected monthly. The whole surface on the sugar cane bagasse was examined from soil level up to a height of 5-8 meters. A sample was considered as one or more sporocarps originated from a single plasmodium. When the intervening distance was at least $30 \mathrm{~cm}$, it was regarded as separate samples as suggested by Eliasson (1981).

Samples analyses and species identification were as described by Martin and Alexopoulos (1969) and Farr (1976) respectivaly. Monthly abundance of sporocarps was evaluated according to the following classification: High -6 or more sporocarps. Mediam - 3 to 5 sporocarps. Scarce or absent -0 to 2 sporocarps.

\section{RESULTS}

Meteorological data for the collecting period are shown in Table 1. Total rainfall during 1997 was $1,906.9 \mathrm{~mm}$, with monthly variations from 15.5 $\mathrm{mm}$ in October to $464.9 \mathrm{~mm}$ in May. Average temperature was always above $20{ }^{\circ} \mathrm{C}$, with a minimum of $17{ }^{\circ} \mathrm{C}$ and a maximum of $32.6{ }^{\circ} \mathrm{C}$. Incident insolation on sugar cane bagasse, stored outdoors in open place, was high, with slight oscillations along the seasons of the year, as moderated during autumn-winter (84.1-128 h).

In the region of, the rain occurs from April to August and weather starts in September, continuing with very low rainfall from October to January. Relative humidity of the air was high during the whole period (above $71 \%$ ), and was higher than $80 \%$ in June, July and August (winter). There was no expressive variations of temperature (annual average $26.3-27.8^{\circ} \mathrm{C}$ ), except a slight temperature decline during the rainy months (from May to August).

Monthly occurrence of sporocarps on sugar cane bagasse, in relation to the number of rainy days during the collecting month and to the accumulated rainfall during the 20 days prior to date when the aethalia were found, is shown in Table 2. Sporulation peak occurred during the months with higher number of rainy days.

The figures 1 and 2 can be used to show that shifting rainfall of February, March, April and May four months further, it was observed that the greater abundance of sporocarps in July, August and September coincides with the peak of rainfall, which corresponds to rain falling down during the preceding four months.

\section{DISCUSSION}

It is known from the literature that rainfall distribution is more important than total rainfall in maintaining substrate humidity for a prolonged period, thus propitiating more favorable conditions for the development of Myxomycetes. 
Nevertheless, in this study, higher monthly rainfall did not coincide with months with higher number of rainy days. During 1997, rainfall, temperature and relative humidity of the air were more or less similar to the average for the ten past years.
Rainfall in June, September and October was sensibly lower, differing from the previous years pattern, probably due to effects caused by El Niño, a climatic phenomenon, which occurred in 1997/1998.

Table 1 - Meteorological data for the months and days when collections of Fuligo septica (L.) Wigg. were performed (INMET- Meteorological Station of Curado, Recife, Pernambuco State, Brazil).

\begin{tabular}{|c|c|c|c|c|c|c|c|c|}
\hline \multirow{2}{*}{$\begin{array}{l}\text { Month/ } \\
\text { year } \\
1997 / 98\end{array}$} & \multicolumn{3}{|c|}{ Precipitation } & \multirow{2}{*}{$\begin{array}{c}\text { Relative } \\
\text { humidity } \\
\text { of the air } \\
(\%)\end{array}$} & \multirow{2}{*}{$\begin{array}{c}\text { Total } \\
\text { insolation } \\
\text { (h) }\end{array}$} & \multicolumn{3}{|c|}{$\begin{array}{c}\text { Air temperature } \\
\left({ }^{\circ} \mathbf{C}\right)\end{array}$} \\
\hline & $\begin{array}{c}\text { Total } \\
\text { height } \\
\text { (mm) }\end{array}$ & $\begin{array}{c}\text { Days } \\
\text { of rain } \\
\left(n^{0}\right)\end{array}$ & $\begin{array}{l}\text { Amount of } \\
20 \text { previous } \\
\text { days (mm) }\end{array}$ & & & $\begin{array}{l}\text { Absolute } \\
\text { maximum }\end{array}$ & $\begin{array}{l}\text { Absolute } \\
\text { minimum }\end{array}$ & $\begin{array}{l}\text { Average } \\
\text { monthly }\end{array}$ \\
\hline January & 30.2 & 13 & 7.3 & 72.0 & 248.4 & 31.8 & 21.2 & 27.7 \\
\hline February & 158.6 & 21 & 153.1 & 76.0 & 151.8 & 31.3 & 21.2 & 26.8 \\
\hline March & 224.4 & 26 & 120.9 & 79.0 & 128.4 & 31.0 & 21.2 & 26.8 \\
\hline April & 362.2 & 22 & 262.0 & 83.0 & 84.1 & 30.8 & 21.1 & 26.2 \\
\hline May & 464.9 & 25 & 193.3 & 85.0 & 92.8 & 29.5 & 21.5 & 25.5 \\
\hline June & 182.2 & 22 & 115.1 & 85.0 & 89.7 & 30.2 & 17.4 & 24.3 \\
\hline July & 205.4 & 27 & 122.8 & 83.0 & 100.9 & 28.3 & 18.0 & 23.9 \\
\hline August & 130.1 & 28 & 91.5 & 82.0 & 123.1 & 28.6 & 18.8 & 24.3 \\
\hline September & 20.5 & 8 & 20.2 & 74.0 & 181.4 & 30.2 & 17.0 & 25.2 \\
\hline October & 15.5 & 5 & 15.5 & 72.0 & 234.8 & 31.0 & 19.3 & 26.5 \\
\hline November & 43.0 & 7 & 43.0 & 71.0 & 217.5 & 30.8 & 19.8 & 26.9 \\
\hline December & 69.4 & 13 & 2.3 & 74.0 & 177.3 & 31.7 & 21.0 & 27.2 \\
\hline January & 75.2 & 14 & 45.5 & 75.0 & 256.2 & 32.6 & 21.7 & 27.8 \\
\hline
\end{tabular}

Table 2 - Abundance of sporocarps of Fuligo septica (L.) Wigg. on sugar cane bagasse stored at the Comphania Indústrias Brasileiras Portela (Jaboatão dos Guararapes, Pernambuco State, Brazil) during January/1997January/1998.

\begin{tabular}{lccccc}
$\begin{array}{c}\text { Month/ } \\
\text { year } \\
\mathbf{1 9 9 7 / 9 8}\end{array}$ & Collection & $\begin{array}{c}\text { Collected } \\
\text { samples } \\
\left(\mathbf{n}^{\mathbf{0}}\right)\end{array}$ & Abundance* & Rain days $\left.\mathbf{( n}^{\mathbf{0}}\right)$ & $\begin{array}{c}\text { Precipitation } \\
(\mathbf{m m})\end{array}$ \\
\hline January & 20 & 0 & Absent & 11 & 7.3 \\
February & 24 & 1 & Scarce & 21 & 153.1 \\
March & 19 & 1 & Scarce & 26 & 120.9 \\
April & 09 & 0 & Absent & 22 & 262.0 \\
May & 13 & 1 & Scarce & 25 & 193.3 \\
June & 02 & 3 & Median & 22 & 115.1 \\
July & 08 & 5 & Median & 27.8 \\
August & 12 & 6 & Abundant & 28 & 91.5 \\
September & 19 & 7 & Abundant & 08 & 20.2 \\
October & 22 & 2 & Scarce & 05 & 15.5 \\
November & 25 & 0 & Absent & 07 & 43.0 \\
December & 18 & 2 & Scarce & 10 & 2.3 \\
January & 13 & 1 & Scarce & 14 & 45.5 \\
\hline
\end{tabular}

* Abundant: $6-8$ sporocarps; Median: 3-5sporocarps; Scarce or absent: 0-2 sporocarps.

** Accumulated rainfall during the 20 days preceding collection.

Higher abundance of sporocarps was found during the months with higher number of rainy days (July and August), though rainfall was not the highest in those days. A mediam abundance of sporocarps was observed in September, though rainfall and number of rainy days were 
among the lowest of the year. The relatively high rainfall in this month and the high number of rainy days (almost 100\%) occurred in July and August caused the high index of sporulation verified in September probably, favoring the development of a higher quantity of plasmodia. An opposite situation was observed in March and April when, though the high values of rainfall, sporocarps were scarce and, only one (March) or no (April) sporocarps were collected.

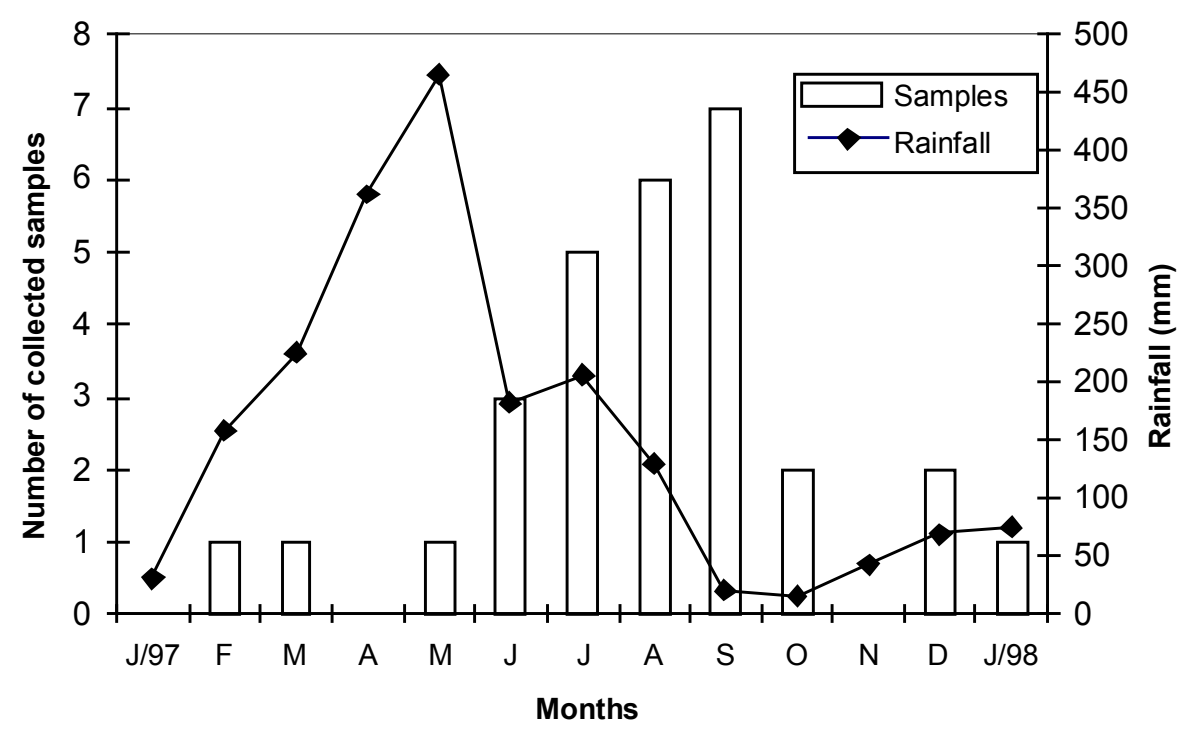

Figure 1 - Relationship between the number of sporocarps of Fuligo septica (L.) Wigg., collected monthly on sugar cane bagasse at the Companhia Indústrias Brasileiras Portela (Jaboatão dos Guararapes, Pernambuco State, Brazil), and monthly rainfall in the same period.

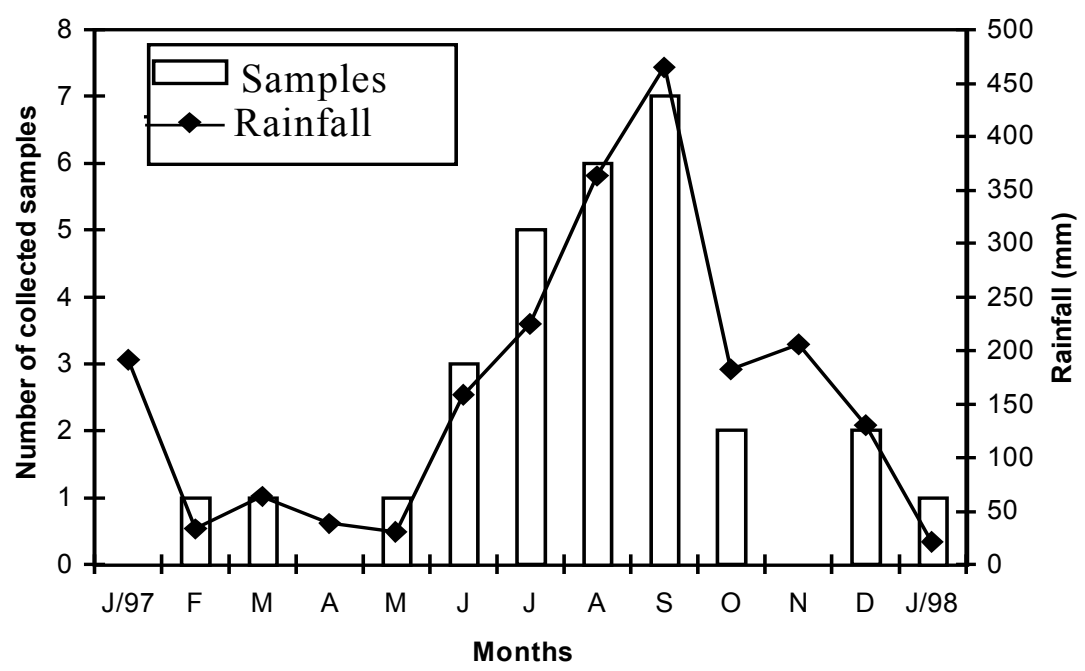

Figure 2 - Relationship between the number of sporocarps of Fuligo septica (L.) Wigg., collected monthly on sugar cane bagasse at the Companhia Indústrias Brasileiras Portela (Jaboatão dos Guararapes, Pernambuco State, Brazil), and monthly rainfall occurred four months prior to sporulation (September/1996-October/1997). Analyzed substrate. 
Thus, reflecting the conditions of low rainfall during the period Dezember/1996-February/1997. Albuquerque (1998), who worked with material collected on sugarcane bagasse, under the same environment and period, reported a similar effect for Lycogala epidendrum (L.) Fries. he observed that sporocarps were much more abundant in July and August, exactly the months under the influence of the heavy rainfall of the preceding two months, which also presented an almost daily distribution of rainfall. These observations confirm the report by Stephenson (1988) on the influence of the rain falling during the two months preceding the collection of samples.

Distribution of rainfall along the collection period should also be considered. In spite of the strong influence of rainfall on the abundance of sporocarps, it is important to consider that abundance is not determined by only one, but by a sum of environmental factors (Ogata et al., 1996). During the study, temperature and relative humidity of the air were more or less constant, with slight daily variations, monthly averages varying in a very narrow range.

While studying the Myxomycetes of the Mata de Dois Irmãos (Recife, Pernambuco State, Brazil) forest reserve, Pôrto (1982) carried out a survey of the number of samples of $F$. septica collected between 1947 and 1980. These data showed that most of the 19 exsiccate, obtained in a period of 33 years were collected in September. In the same work, where 24 excursions were performed in a period of 12 months, was recorded the occurrence of only one aethalium. Thus, F. septica may be considered as rare in that site. Comparing these data with those obtained for sugarcane bagasse stored in the paper industry Portela, with 29 records in 13 excursions (some with more than one aethalium), it is evident that the environment and substratum studied are more suitable for the development of $F$. septica than that provided by the Atlantic forest studied by Pôrto (1982).

In the present work, not only the presence of sporocarps of $F$. septica during the analyzed period seemed to be strongly related with rainfall, but also its peak of sporulation, which occurred during the months with higher number of rainy days and, as a consequence, when the substrate remained with an appropriate humidity. Yet, according to Ogata et al. (1996), it has to be considered that an excessively humid substrate may favor plasmodia phase and delay sporulation.
This could explain why there were no records and their scarcity in May in the analyzed substrate.

The low rainfall recorded in October, November and January/1996, explained the absence of sporocarps in January/1997. A similar situation happening in 1997 explained the low abundance (only one sporocarp) in January/1998.

The large number of sporocarps of $F$. septica observed in August and September on sugarcane bagasse indicates that there was a higher abundance of plasmodia in the period immediately prior to sporulation. However, such abundance was difficult to evaluate, because the plasmodium, though it could reach an appreciable size, remained on the sub-superficial layers of the substrate, only emerging when it was prompt to sporulate. Our results for sugarcane bagasse stored outdoors agreed with the Pôrto and Cavalcanti (1984) for seasonal perennial coastal forest.

\section{RESUMO}

A influência de fatores ambientais na esporulação de Fuligo septica (L.) Wigg. e aabundância desta espécie em bagaço de cana de açúcar (Saccharum officinarum L.), armazenado ao ar livre, foram estudadas. Entre janeiro/1997 e janeiro/1998, um total de 29 espécimes foi coletado em coletas mensais de esporocarpos (etálios). A relação entre a abundância de etálios e precipitação pluviométrica, temperatura, umidade relativa do ar e insolação foi estudada. Os resultados indicam que $F$. septica é uma espécie abundante no substrato analisado. A esporulação acontece em todas as estações do ano, com um pico bem definido ao término do inverno e início da primavera (agosto/setembro), fortemente influenciado pelas chuvas.

\section{REFERENCES}

Albuquerque, S. S. M. C. (1998), Atividade antimicrobiana dos extratos de etálios Lycogala epidendrum (L.) Fries de Federal Rural de Pernambuco, Recife (PE), Brazil.

Alexopoulos, C. J.; Mims, C. W. and Blackwell, M (1996), Introductory Mycology. New York : John Wiley and Sons, Inc. pp. 775-808.

Comparative Ecological Study. Nova Hedwigia, 34, 207-246. 
Eliasson, U. (1981), Patterns of occurence of Myxomycetes in a spruce forest in south Sweeden. Holoartctc Ecology, 4, 20 - 31.

Farr, M. L. (1976), Myxomycetes. Flora Neotropica. New York : New York Botanical Garden. pp. 107-112.

Gianini, E. H.; Northey, W. T. and Leathers, C. R. (1975), The allergenic significance of certain fungi rarely reported as allergens. Annals of Allergy, 35, 372-376.

Lacey, J. (1974), Moulding of Sugarcane bagasse and its prevention. Annals of Applied Biology, 7663-76.

Maimoni-Rodella, R. C. S. and Gottsberger, G. (1980), Myxomycetes from the forest and the cerrado vegetation in Botucatu, Brazil.

Martin, G. W. and Alexopoulos,C. J. (1969), The Myxomycetes. Iowa : University of Iowa Press. pp.12-22.

McElhenney, T. B. and McGovern, J. P. (1970), Possible new inhalant allergens. Annals of Allergy, 28, 467-471.

Ogata, N.; Rico-Gray, V. and Nestel, D. (1996), Abundance, richness and diversity of Myxomycetes in a Neotropical forest ravine. Biotropica, 28, 627-635.

Pôrto, K. C. (1982), Myxomycetes da mata de Dois Irmãos (Recife - Pernambuco). Universidade Federal de Pernambuco, Recife (PE), Brazil.
Pôrto, K. C. and Cavalcanti, L. H. (1984), Myxomycetes da Floresta Estacional perenifolia Costeira (Recife-PE) I. Influência de fatores climáticos. In: Anais Congresso Nacional de Botânica 34. 1983. Brasília : Embrapa. pp. 407-416.

Santilli, J.; Rockwell, W. J. and Collins, R. P. (1985) The significance of the spore of the Basidiomycetes (Mushrooms and their allies) in bronchial asthma and allergenic rhinitis. Annals of Allergy, 55, 469-471.

Stephenson, S. L. (1988), Distribution and ecology of Myxomycetes in temperate forests. I. Patterns of occurrence in the upland forests of Southwestern Virginia. Canadian Journal of Botany, 66, 2187-2207.
Received: April 18, 2001;

Revised: July 27, 2001; Accepted: January 28, 2002. 